\title{
Employability and Personal Initiative as Antecedents of Job Satisfaction
}

\author{
Juan Pablo Gamboa, Francisco Gracia, Pilar Ripoll, and José María Peiró \\ Universitat de València (Spain)
}

\begin{abstract}
In a changing and flexible labour market it is important to clarify the role of environmental and personal variables that contribute to obtaining adequate levels of job satisfaction. The aim of the present study is to analyze the direct effects of employability and personal initiative on intrinsic, extrinsic and social job satisfaction, clarifying their cumulative and interactive effects. The study has been carried out in a sample of 1319 young Spanish workers. Hypotheses were tested by means of the moderated hierarchical regression analysis. Results show that employability and personal initiative predict in a cumulative way the intrinsic, extrinsic and social job satisfaction. Moreover, the interaction between employability and personal initiative increases the prediction of these two variables on intrinsic and extrinsic job satisfaction. Results also indicate that higher values of employability when initiative is also high are associated to higher levels of intrinsic and extrinsic satisfaction. These results have implications for theory and practice in a context of new employment relations.
\end{abstract}

Keywords: employability, personal initiative and job satisfaction.

\begin{abstract}
En un mercado laboral cambiante y flexible, es importante clarificar el papel de variables ambientales y personales que permitan obtener niveles adecuados de satisfacción laboral. El objetivo de este trabajo es analizar el efecto directo de la empleabilidad y la iniciativa personal sobre la satisfacción laboral intrínseca, extrínseca y social, clarificando si esos efectos son acumulativos e interactivos. El estudio se realizó con una muestra de 1319 trabajadores españoles jóvenes. Las hipótesis se probaron por medio del análisis de regresión jerárquica modulado. Los resultados muestran que la empleabilidad y la iniciativa personal contribuyen de forma acumulativa a predecir la satisfacción extrínseca, intrínseca y social y su interacción incrementa la predicción de la satisfacción extrínseca e intrínseca. Los resultados también indican que niveles altos de empleabilidad, cuando la iniciativa personal es alta, se asocian con niveles mayores de satisfacción extrínseca e intrínseca. Estos resultados tienen implicaciones teóricas y prácticas para las relaciones laborales actuales.
\end{abstract}

Palabras clave: empleabilidad, iniciativa personal, satisfacción laboral.

The authors would like to thank the BANCAJA Foundation and the IVIE for their financial support and for the development of the Observatory of the Transition of Young People into the Labour Market, whose database this present study is based on; and also the IVIE for their help in carrying out this research, which is part of the project CONSOLIDER 2006-14086/SIC.

Correspondence concerning this article should be addressed to Juan Pablo Gamboa Navarro. Departamento de Psicología Social, Facultad de Psicología, Universitat de València, Av. Blasco Ibáñez, 21, 46010, Valencia (Spain). Phone: +34-963390991. Fax: +34963620471. E-mail: juan.gamboa@uv.es 
The transformations that have taken place in the work climate have led to changes in the relationships between employees and organizations, caused by the demand for greater flexibility on the part of firms (Gracia, MartínezTur \& Peiró, 2001) and workers (Peiró, García-Montalvo \& Gracia, 2002). This change is depicted as the transition from the old to the new psychological contract (Herriot \& Pemberton, 1995; Tsui, Pearce, Porter \& Tripoli, 1997), meaning that the transformations have occurred which Guest and Conway (2002) defined as "The perceptions of both parties to the employment relationship - organisation and individual - of the reciprocal promises and obligations implied in that relationship" (p. 22).

The "old" psychological contract was a paternalist one (Kochan, 1998), rewarding employees' loyalty and commitment with job security and a predictable system of improvements (e.g. promotions) (Cappelli, 1995). Nowadays, more is required from workers than some years ago, mainly because of organisational flexibility. However, the stability and career development of the past are not guaranteed. This leads us to question what a worker can be offered in exchange for the high levels of initiative, engagement and performance that are being demanded of them.

One of the possible answers to this question is the configuration of a new psychological contract that balances the scales by providing opportunities which strengthen workers' employability (Altman \& Post, 1996; Herriot \& Pemberton, 1995; 1997). That is, giving them the possibility to attain skills which are attractive to a wide range of employers will allow them to obtain work in different organisations (Arthur \& Rousseau, 1996), therefore reducing job insecurity. An alternative could be to establish personalized employment agreements which meet the needs of the worker as well as the interests of the firm (Rousseau, 2001; 2005; Rousseau, Ho \& Greenberg, 2006).

Given all these changes in the psychological contract, one can ask if it is still possible for workers to obtain adequate levels of job satisfaction in a context which is less and less paternalist (Altman \& Post, 1996), and labour relations are becoming more and more individualist. According to García-Montalvo, Peiró and Soro (2003), job satisfaction means:

An overall positive attitude towards different aspects of the work experience, which implies an appreciation of the work situation in different aspects and to what extent this situation responds to expectations and aspirations. (p.424).

Therefore, the satisfaction workers can derive from extrinsic, intrinsic and social aspects of work turns out to be significant (which will be defined briefly in the method section).

In response to the question we posed, we consider that given the changes that have taken place, job satisfaction can at least be partly explained in the present environment with variables which have not been considered in the classic models of job satisfaction. The basis of our argument is that in such a competitive environment where excellence is required rather than simply fulfilling duties, and where collective agreements have weakened in view of the individualization of relationships, job satisfaction may depend on an individual's capacities related to work, which have not been taken into account in classic models of job satisfaction. For this reason, the present study aims to determine to what extent factors such as employability and personal initiative contribute, both independently and interactively, to predicting satisfaction with different aspects of work.

However, when analysing what makes it possible to work under satisfactory labour conditions nowadays, we must consider alternative analysis frameworks for current working relationships. In a context where individualization is growing in working relationships, Rousseau et al. (2006) propose the idiosyncratic deals as an analytical framework applicable to this case.

In particular, the idiosyncratic deals "refer to voluntary, personalized agreements of a non-standard nature negotiated between individual employees and their employers regarding terms benefiting each party". These agreements represent a useful mechanism when it comes to attracting, motivating, satisfying and keeping the best workers who add value to a firm. It is because of this value that these workers have a greater ability than others to negotiate the terms of their relation (Rousseau et al., 2006, p.978).

According to Rousseau (2001), the increasing demand in a competitive market for valuable workers with high qualifications and distinctive skills gives these workers more power to negotiate personalized working conditions, adjusted to suit their needs. In addition, they can establish idiosynchratic deals regarding aspects such as the level or responsibilities of the job, among other questions. This greater capacity to negotiate employment conditions and to adjust them to suit their needs, both upon entering an organization and also during the time there, allows them to derive a higher level of job satisfaction.

From the definitions of employability, we can see that employable people possess the distinctive skills mentioned by Rousseau (2001) needed to negotiate their employment conditions with their employers and obtain satisfactory jobs more easily.

The above mentioned is proven in definitions of employability such as that by Hillage and Pollard (1998), who describe it as an individual's ability to gain initial employment, maintain employment, move between roles within the same organisation, obtain new employment if required and (ideally) secure suitable and sufficiently fulfilling work. According to these authors, employable people possess different and transferable skills, and prove themselves to their employers. They also have strategies for their career development and for looking for the right job, as well as personal characteristics which interact with the labour market appropriately. 
Despite the variety of conceptualizations and operationalizations regarding employability, Gazier (1998) affirms that a certain level of agreement has been reached on an interactive definition of the concept. It is recognised that an individual's employability and the value it represents for employers are relative to the following: the labour context; others' employability and opportunities; the rules of the market, the institutions, the employers and their attitudes; the level of demand for workers; and socioeconomic factors, among other factors (McQuaid \& Lindsay, 2005).

On the basis of these conceptualizations, in this study we consider employability to be an individual's subjective perception of the opportunities they have to obtain a job of their choice or to improve their present one, depending on their personal characteristics and the labour market. In terms of personal characteristics, this perception of opportunities in the labour market depends a great deal on the human capital (that is, training, work experience, skills, abilities, knowledge and other characteristics) accumulated over time through education and professional experience. This perception is also influenced by knowledge of the labour market dynamics, as regards the offer of employment and the demand of workers with human capital and personal characteristics similar to their own. Human capital therefore increases perceived employability to the extent that it represents abilities valued by employers and which can be shown in different work contexts.

Fugate, Kinicki and Ashforth (2004) consider that this social and human capital is combined with career identity and personal adaptability, thus shaping individual employability. These factors affect both the ability to find work, as well as the type of work obtained. Because employable people have human capital that enables them to fulfil employers' expectations, it not only makes them more appealing to employers but also gives them more and better choices of work and allows them to establish idiosyncratic deals which are beneficial to their job satisfaction.

Human capital also allows people to consider and look for alternative work, which is coherent with their career identity, as well as their personal characteristics and expectations (Fugate et al., 2004). These people have, therefore, a clear idea of the type of jobs that can help them achieve their career objectives, and continue their search until they have obtained work which they find satisfactory (McArdle, Waters, Briscoe \& Hall, 2007). For example, employable university graduates have oportunities of finding and maintaining "knowledge work" which fits their labour preferences and expectations and also fosters their satisfaction with intrinsic aspects of this work (Brown, Hesketh \& Williams, 2003, p.122).

In addition, employable people's human capital fosters the formation of labour expectations which are adjusted to the characteristics of the labour market. The job searching process is therefore shorter and more efficient, achieving fit between labour expectations and preferences, and the jobs obtained (Vila, 2000; 2005).

Although the human capital theory suggests that the investments made to increase this capital will increase the economic returns of these investments in the long run (Becker, 1964), it is clear that the benefits of this type of investment are not only economic but also make a direct contribution to increasing well-being at work (Vila, 2005). Thus, a "knowledge work" obtained from these investments can be a source of enjoyment, creativity, personal development and beneficial to extrinsic aspects of work, such as the salary and benefits package (Brown et al., 2003).

However, the theory also predicts that human capital can be related to a higher level of satisfaction regarding the social aspects of work. This is because those with high human capital, such as employable people, reach an occupational status (Becker, 1964), which means more social recognition, better labour conditions and more possibility of improving them. Those with high employability tend to accept high status jobs, according to Rothwell and Arnold, (2007), because "feel they have built up a good reputation and set of skills and experiences that will make them both valuable in their current job and attractive to alternative employers" (p.37).

Taking into account the job fit theories, if employable people have the ability to obtain work with characteristics which fit their own needs and characteristics, they will be more satisfied at work (Brkich, Jeffs \& Carless, 2002). The empirical studies show that the fit between personal characteristics and labour characteristics correlate highly and significantly with job satisfaction (Kristof, Zimmerman \& Johnson, 2005).

However, when revising previous literature, there is no empirical evidence on the effects that employability has on aspects of job satisfaction. Therefore, we propose a hypothesis that the higher a worker's perceived employability is, the greater will be their extrinsic (H1a), social (H1b) and intrinsic (H1c) satisfaction.

Personal initiative is another key variable in looking for and obtaining quality employment, as well as in the negotiation of labour conditions. It is defined as "behaviour syndrome resulting in an individual's taking an active and self-starting approach to work and going beyond what is formally required in a given job" (Frese, Kring, Soose and Zempel, 1996, p. 38). Those with initiative focus on longterm goals and ways to achieve them. They are persistent and prove this both in the workplace by generating changes in their position to make it more challenging, adjusted and satisfactory (Frese, Fay, Hilbuerger, Leng \& Tag, 1997), and also when they need to obtain another job (Frese \& Fay, 2001).

People with initiative are active in improving their labour situation, in a context where employees are becoming more 
and more responsible for managing their careers. This was characterized by Sullivan (1999) as "protean career" where initiative plays a key role in professional development and generating employment opportunities (Fugate, Kinicki \& Ashforth, 2004).

The empirical results obtained by Frese et al. (1997) show that personal initiative is related to clearer career plans and their implementation, as well as to higher employability. This indicates that those with initiative identify the most adjusted labour opportunities, and persist in attaining them in order to derive high levels of job satisfaction.

Nevertheless, the available empirical evidence is limited and its conclusions are unclear. In particular, Frese et al. (1997) found a significant positive correlation between an objective measurement of initiative and general job satisfaction. However, with a second sample, only a positive correlation is obtained between a self-report measurement of initiative and a general measurement of job satisfaction.

In a similar area, studies on proactive personality provide some indirect evidence. Erdogan and Bauer (2005) and Pinazo, Peiró, Carrero and Rosel (1999) find that employees with proactive personality are more satisfied because they eliminate situations which could be detrimental to their job. However, these studies use a general measurement of job satisfaction without identifying any differences in its facets.

In this study, we analyse in depth the relation between the perception of initiative and the facets of job satisfaction. We put forward the hypothesis that the more initiative a worker has, the greater will be their extrinsic $(\mathrm{H} 2 \mathrm{a})$, social (H2b) and intrinsic (H2c) satisfaction.

As was already stated, employability refers to how suitable a worker's preparation and qualifications are to the demands of the labour market, being maintained by continuous training, which allows the worker to obtain good jobs easily. Personal initiative entails anticipation, persistence and overcoming difficulties to achieve goals at work. Both of these characteristics play an important role in fostering employees' satisfaction because of the possibility to negotiate and modify the extrinsic, social and intrinsic characteristics of work, and the value that employable workers with personal initiative represent for firms.

The consideration of employability and initiative jointly as new antecedents for job satisfaction leads us to question the existence of interactive effects between employability as a predictor variable and initiative as a moderator variable, in a way which increases the explanatory capacity of satisfaction as a criterion variable. According to what has been proposed, we are more inclined towards a positive answer and propose the hypothesis that workers with high employability and initiative show a greater level of extrinsic (H3a), social (H3b) and intrinsic (H3c) satisfaction.
Method

\section{Participants}

The present study was conducted with a subsample of 1319 young people, taken from a general sample of 2512 , 16 to 30 years old residents in the Valencian Community, and in the cities of Madrid and Barcelona (Spain), and was obtained in 1999 by the Observatory of Young People's Transition into the Labour Market in the Valencian Community (Bancaja-IVIE). The studied subsample is made up exclusively of young people who were working at the time of the survey. The term worker is used on condition that the participants were doing some kind of paid work, for at least an hour during the week before the survey. The condition of worker allows us to see the participants' scores in the variables of interest from the study. Some $54.6 \%$ of the sample are males and the average age is 24.8 years old (S.D. $=3.74)$. The distribution according to level of studies is: (1) $35.9 \%$ with primary school education; (2) $44.2 \%$ with secondary school education; (3) $11.1 \%$ have a diploma after 3 years of university studies and (4) $8.8 \%$ are postgraduates (have a 5 year university degree).

\section{Procedure}

Data from the study was gathered from a survey which was conducted at the same time as a face to face interview lasting approximately 25 minutes, with all data being obtained by means of self-report. Following two attempts at being contacted, the people who did not answer were replaced by a substitute of the same age and gender, chosen randomly.

\section{Instruments and variables}

Gender and level of education were considered as control variables, given that they are frequently related to employability (predictor variable), personal initiative (moderator variable) and job satisfaction (criterion variable).

Employability. Measures people's perceptions about their own possibilities in the current labour market, using two items from the Scale "Employment Outlook" from the Career Exploration Survey (Stumpf, Colarelli \& Hartman, 1983). A Likert scale was used with a choice of 5 answers, ranging from 1 (strongly disagree) to 5 (strongly agree). The items were: "In the current labour market, it seems possible to find work for which I am prepared or have experience" and "In the current market I find it possible to work in a firm of my choice". The Spanish version of this scale was validated and previously used by Ripoll, Rodríguez, Hontangas, Peiró and Prieto (1994). The reliability of the scale, Cronbach's Alpha is .76.

Personal Initiative. This was measured by means of 3 items from a scale developed by Frese et al. (1997). A Likert 
scale was used with a choice of 5 answers, ranging from 1 (strongly disagree) to 5 (strongly agree). The items were: "I use opportunities quickly in order to attain my goals" "I take initiative immediately even when others don't" and "Usually I do more than I am asked to do". The scale was translated from its original version in English using the direct and inverse method of translation (translation and countertranslation.). In other words, first the items were translated from English to Spanish and then translated back to English in order to test the equivalent meanings between the languages. The reliability of the scale, Cronbach's Alpha, is .70 .

Job satisfaction. A generic measure is used which assesses satisfaction with the 3 classic facets considered in the literature, by means of 19 aspects of work grouped in this way: 7 extrinsic aspects, 5 social aspects and 7 intrinsic aspects. A Likert scale was used with a choice of 5 answers ranging from 1 (highly dissatisfied) to 5 (highly satisfied). The reliability, Cronbach's Alpha is .81 for the sub-scale of extrinsic aspects, .75 for the sub-scale of social aspects and .78 for the sub-scale of intrinsic aspects.

The measure of the facets of satisfaction is based on García-Montalvo et al. (2003), who describe extrinsic satisfaction as an "emotional response or general attitude towards extrinsic aspects of the labour activity itself, such as economic resources, stability at work, promotion opportunities, or labour conditions". Intrinsic satisfaction is characterized as "an emotional response to aspects of the job itself" such as opportunities to learn, the variety of tasks, the skills required for a given job and autonomy. Finally, satisfaction with social aspects implies "the social significance and assessment of an activity as well as the social relationships (colleagues, supervisors, subordinates, clients, etc.)" (p.424).

All of the scales used in this study follow the reliability criteria of .70, proposed by Nunnaly and Berstein (1994).

\section{Data analysis}

The hypotheses are tested by means of moderated hierarchical regression analysis. The predictor variables (employability) and moderator (initiative) and the interaction terms are introduced in the regression equation in three successive steps: First, control variables, which are gender (man and woman) and level of education (primary, secondary and university -diploma: three-year university degree and postgraduate: five-year university degree); second, main effects of employability as a predictor variable and of initiative as a moderator variable; and third, interaction term, calculated as the product of predictor and moderator variables. In order to decrease the effects of multicolinearity (Cohen, Cohen, West \& Aiken, 2003), differential scores were calculated and used (regarding the means) in the predictor and moderator variables.
Results

Table 1 shows the means and standard deviations of the variables included in the study.

The moderated hierarchical regression analysis shows that both employability and personal initiative make a statistically significant contribution to explaining the satisfaction variance with the three aspects of work considered. Table 2 shows that employability $(\beta=.173, p$ $\leq .001)$ and initiative $(\beta=.107, p \leq .001)$ contribute to predicting satisfaction with extrinsic aspects in a way which is statistically significant. Table 3 equally shows that employability $(\beta=.131, p \leq .001)$ and initiative $(\beta=.175$, $p \leq .001)$ contribute in a statistically significant way to explaining the satisfaction with social aspects. In the same way, Table 4 indicates that employability $(\beta=.164, p \leq$ $.001)$ and initiative $(\beta=.234, p \leq .001)$ make a statistically significant contribution to explaining satisfaction with intrinsic aspects of work, thus confirming the hypotheses H1a, H1b, H1c and H2a, H2b and H2c. Furthermore, Table 2 indicates that the interaction of employability and initiative also contribute significantly to explaining the satisfaction

Table 1

Means and Standard Deviations of the variables included in the study $(N=1319)$

\begin{tabular}{lcc}
\hline Variables & $\mathrm{M}$ & $\mathrm{DT}$ \\
\hline 1. Gender & - & - \\
2. Level of Education & - & - \\
3. Extrinsic Satisfaction & 3.63 & .74 \\
4. Social Satisfaction & 3.86 & .73 \\
5. Intrinsic Satisfaction & 3.81 & .75 \\
6. Employability & 2.76 & 1.14 \\
7. Initiative & 3.89 & .65 \\
\hline
\end{tabular}

Table 2

Moderated Hierarchical Regression Analysis: Main effects and Interaction of Employability and Initiative on Satisfaction with Extrinsic Aspects $(N=1024)$

\begin{tabular}{lccc}
\hline Variables & $B$ & $B E T$ & $\beta$ \\
\hline Step 1 & & & \\
$\quad$ Gender & -.093 & 0.046 & $-.063^{*}$ \\
$\quad$ Level of Studies & .050 & 0.026 & $.061^{*}$ \\
Step 2 & & & \\
$\quad$ Employability & .112 & 0.020 & $.173^{* * *}$ \\
$\quad$ Initiative & .117 & 0.034 & $.107^{* * *}$ \\
$\quad$ Step 3 & & & \\
$\quad$ Employability x Initiative & .079 & 0.028 & $.086^{* *}$ \\
\hline
\end{tabular}

Note. $R^{2}=.007$ for Step $1 ; \Delta R^{2}=.048$ for Step $2(p<.001)$;

$R^{2}=.052$ for Step $2 ; \Delta R^{2}=.007$ for Step $3(p<.01) ; R^{2}=.061$

for Step 3.

$* p<.05 * * p<.01 * * * p<.001$. 
Table 3

Moderated Hierarchical Regression Analysis: Main effects and Interaction of Employability and Initiative on Satisfaction with Social Aspects $(N=1030)$

\begin{tabular}{lccc}
\hline Variables & $B$ & $B E T$ & $\beta$ \\
\hline Step 1 & & & \\
$\quad$ Gender & -.011 & 0.045 & -.008 \\
$\quad$ Level of Studies & .110 & 0.025 & $.136^{* * *}$ \\
Step 2 & & & \\
$\quad$ Employability & .084 & 0.019 & $.131^{* * *}$ \\
$\quad$ Initiative & .191 & 0.033 & $.175^{* * *}$ \\
Step 3 & & & \\
$\quad$ Employability x Initiative & .025 & 0.028 & .027 \\
\hline
\end{tabular}

Note. $R^{2}=.018$ for Step $1 ; \Delta R^{2}=.052$ for Step $2(p<.001)$; $R^{2}=.070$ for Step $2 ; \Delta R^{2}=.001$ for Step $3(\mathrm{~ns}) ; R^{2}=.071$ for

Step 3 .

$* p<.05 * * p<.01 * * * p<.001$.

Table 4

Moderated Hierarchical Regression Analysis: Main effects and Interaction of Employability and Initiative on Satisfaction with Intrinsic Aspects $(N=1024)$

\begin{tabular}{lccc}
\hline Variables & $B$ & $B E T$ & $\beta$ \\
\hline Step 1 & & & \\
$\quad$ Gender & -.053 & 0.047 & -.035 \\
$\quad$ Level of Studies & .105 & 0.026 & $.126^{* * *}$ \\
$\quad$ Step 2 & & & \\
$\quad$ Employability & .109 & 0.020 & $.164^{* * *}$ \\
$\quad$ Initiative & .265 & 0.034 & $.234^{* * *}$ \\
$\quad$ Step 3 & & & \\
$\quad$ Employability x Initiative & .082 & 0.028 & .086 \\
\hline
\end{tabular}

Note. $R^{2}=.016$ for Step $1 ; \Delta R^{2}=.088$ for Step $2(p<.001)$;

$R^{2}=.104$ for Step $2 ; \Delta R^{2}=.007$ for Step $3(p<.01) ; R^{2}=.112$ for Step 3.

$* p<.05 * * p<.01 * * * p<.001$.

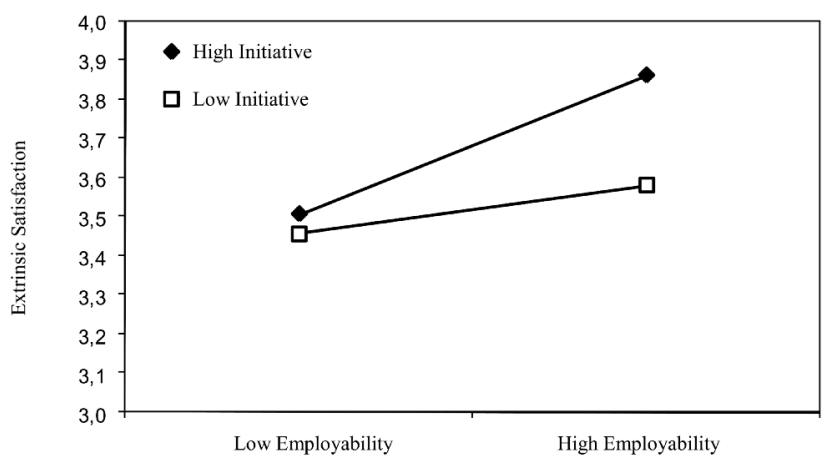

Figure 1. Effects of the Interaction of Employability and Initiative on Satisfaction with Extrinsic Aspects. variance with extrinsic aspects $(\beta=.086, p \leq .01)$. Table 4 shows similar interaction effects of these two variables on the variance of satisfaction with intrinsic aspects $(\beta=$ $.086, p \leq .01)$. On the other hand, Table 3 shows that the interaction of employability and initiative do not contribute to explaining satisfaction with the social aspects of work. The results therefore confirm hypotheses $\mathrm{H} 3 \mathrm{a}$ and $\mathrm{H} 3 \mathrm{c}$, but not hypotheses $\mathrm{H} 3 \mathrm{~b}$.

In order to make clear the interpretation of these results, Figures 1 and 2 show the significant interaction effects by means of graphic representation.

As can be seen in Figure 1, a high level of employability produces more satisfaction with extrinsic aspects when initiative is high than when it is low. However, the levels of satisfaction are practically identical when employability is low, whether initiative is high or low. Likewise, Figure 2 indicates that people with high levels of employability and initiative, derive more satisfaction from the intrinsic aspects of their work than people who do not show high levels of these two characteristics simultaneously. The previous statement confirms the hypothesis of initiative as a moderator variable, in the relationship between employability and satisfaction with extrinsic and intrinsic aspects of work.

\section{Discusión}

The aim of the present work was to determine the direct predictor role of employability and personal initiative and their interaction, in extrinsic, intrinsic and social dimensions of job satisfaction. Authors such as Forrier and Sels (2003) and Hillage and Pollard (1998) suggest that employable people obtain work which they find satisfactory. This might be caused by the fact that employability is highly valuable in the labour market and therefore enables one to chose and negotiate conditions at work. On the other hand, the market value of employable people might be determined by their high human capital; that is to say, knowledge, skills

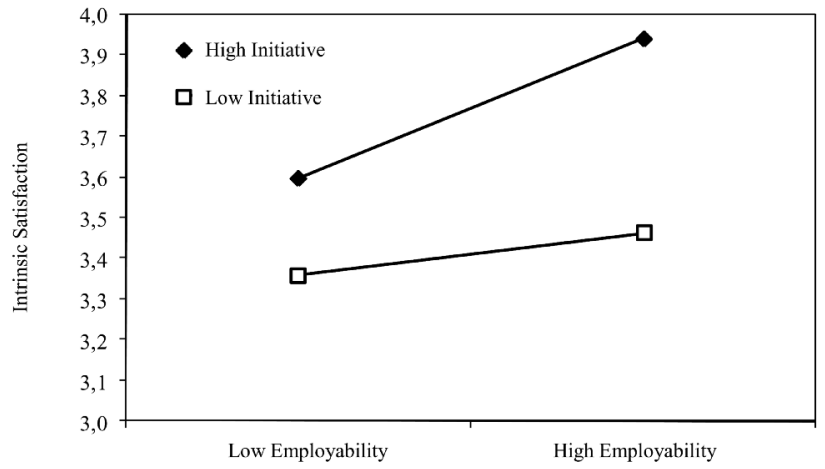

Figure 2. Effects of the Interaction of Employability and Initiative on Satisfaction with Intrinsic Aspects. 
and the experience required to respond to the demands of firms and to perform their work efficiently.

According to the studies by Frese and colleagues, personal initiative might have positive effects on job satisfaction because this quality allows people to identify a range of labour opportunities proactively, and to select the most suitable or the most flexible in terms of negotiating employment conditions. Therefore, once the job has been obtained, initiative makes it possible to introduce changes at work in order to make it more satisfactory.

Taking into account the aforementioned, hypotheses $\mathrm{H} 1 \mathrm{a}, \mathrm{H} 1 \mathrm{~b}, \mathrm{H} 1 \mathrm{c}$ and H2a, H2b, H2c of the study establish that employability and personal initiative individually predict satisfaction with extrinsic, social and intrinsic aspects of work. The results confirm these hypotheses for the three cases. Employability and initiative have additive effects on satisfaction with extrinsic aspects, explaining about 5\% of its variance and although these variables contribute significantly to the proportion of the explained variance, the standard coefficients show that employability predicts a greater amount of extrinsic satisfaction than initiative. Employability and initiative also make a significant contribution individually to explaining satisfaction with social aspects of work, explaining $7 \%$ of its variance. In this case, it is personal initiative which contributes to a greater extent to the proportion of explained variance. In terms of intrinsic satisfaction, the predictor and moderator variables also have an additive effect which is significant in explaining about $10 \%$ of the variance. However, once again it is initiative which has the most weight in predicting this facet of satisfaction.

Hypothesis 3 establishes that employability and initiative also have multiplicative effects on the three facets of satisfaction. Including the interaction term of predictor and moderator variables in the regression models, a small but significant increase can be observed in the predictor power of the proposed models, which allows an explanation of $6 \%$ of the variance of extrinsic satisfaction and $11 \%$ of intrinsic satisfaction. In the case of social satisfaction, no significant increase is observed when including the term of interaction in the equation. These results indicate that a good perception of one's opportunities in the labour market combined with a high level of personal initiative increases satisfaction with extrinsic and intrinsic aspects of work, much more than these two variables independently.

A possible explanation for the effects shown by the interaction between employability and personal initiative is that people with high employability obtain jobs that fit their level of education, their experience and in firms of their preference because they have the initiative to look for them in an appropriate way, as well as the ability to bring about positive changes in important aspects of their work. It does seem, therefore, that people with these two personal characteristics have a positive influence on aspects which are directly linked with work (intrinsic aspects) and on those which depend on their performance (extrinsic aspects), more than on simply social aspects, which seem to be influenced by personal initiative.

A further mechanism which might explain the relationships found are related to the negotiations of personalized agreements in the extrinsic and intrinsic aspects of a given job, in an attempt by employers to motivate, satisfy and maintain employable workers who also show a high level of personal initiative. In addition, they might also offer the possibility of extending this personalized agreement to other terms of employment once it becomes clear that the performance of a given employee is beneficial to the organization (Rousseau et al., 2006). The social aspects of work, however, might not be so easily negotiable.

Future research could explore specific aspects related to the negotiation of working conditions between employable people and employers, which allows them to obtain more satisfactory jobs. This analysis could be done by measuring aspects such as the content and fulfilment of the psychological contract on the employer's part. It is likely that employable people with personal initiative have a better understanding of the relationship with the employer: they receive more promises and assumed obligations from them which are fulfilled, positively influencing their job satisfaction. It is therefore necessary to identify empirically the variables which explain the connection found between employability, personal initiative and job satisfaction.

In the same vein, future research could extend the analysis to samples of temporary and permanent workers to confirm if employability and initiative have the same additive and multiplicative effects on their job satisfaction. It would also be interesting for future studies to analyze the effects that the combination of high employability and initiative has on other indicators of quality of life and wellbeing at work.

The results obtained indicate there is progress in the knowledge on employability, personal initiative and how they are related to job satisfaction, in particular regarding young people, who are the most affected by the new forms of contracts and employment. Previous evidence was almost non-existent for the relation between employability and job satisfaction and undefined regarding initiative. Thus, these results provide discreet but significant evidence of the positive effects that employability has on satisfaction proposed by Forrier and Sels (2003) and Hillage and Pollard (1998) of the effects of initiative already pointed out by Frese et al. (1997) and of the interaction of these two variables.

In addition, some theoretical implications are also derived from the present study. First, the findings of personal variables that also take into account the current labour context, and which up until now were unrelated with explaining job satisfaction. Personal initiative has therefore been identified as a variable which is strictly related to employability and these two variables as predictors of 
satisfaction, opening a line of research on new correlates of these variables. Furthermore, the results also indirectly support the approach of Becker's Human Capital Theory (1964) that investing in the development of skills is rewarded by obtaining better jobs as a "return on the investment". In other words, a satisfactory job could be seen as a reward for the above mentioned development.

The study also has significant practical applications. Given that more and more young people are experiencing precarious job situations, the low quality of many of their jobs has a significant effect on their satisfaction with work. Thus, the results from the study show that interventions to increase young people's employability are important not only for their labour transition, but also for a transition of quality, to the extent that it enables them to obtain more satisfactory jobs, particularly in aspects such as the type of job they do (intrinsic aspects), and the benefits derived from the job (extrinsic aspects). However, the results indicate that young people obtain more satisfactory jobs when they show high levels of personal initiative. In view of this, programmes by universities, educational centres, and the government aimed at the transition of young people into the labour market, as well as improving the quality of employment they obtain, should include activities which develop jointly employability and personal initiative, given that employability or initiative alone are not enough in today's labour market.

It is expected that these types of interventions will not only improve the quality of young people's working life, but also have an impact on the quality of their life in general, given the well-known effects that job satisfaction has on satisfaction with life on the whole.

This study presents certain limitations. The use of selfreport measures could induce method and common source variance, so precaution must be taken when analyzing the results. Future research could use behaviour measures of personal initiative (Frese \& Fay, 2001), and employability measures could combine subjective aspects (individual) with objective indicators (contextual). On the other hand, the cross-sectional design used limits the interpretation of causal relations between variables and suggests that future research considers longitudinal designs in order to establish causal types of relations between employability, personal initiative and the dimensions of job satisfaction.

A further limitation of the study is the low percentages of explained variance for personal initiative and employability. However, although these variables explain in an additive way less than $10 \%$ of the variance of each dimension, in the introduction of their interaction term the regression equations increase moderately, but significantly, the explained variance of extrinsic and intrinsic satisfaction. These results do not rule out the predictor role of employability, initiative and their interaction. On the contrary, their measures need to be refined and other predictor and moderator variables related to them need to be introduced so that the criterion variables gain explanatory power. Thus, it is possible that the relationship between employability, initiative and job satisfaction is not a direct one, and that there are variables such as the psychological contract which mediate this relation.

\section{References}

Altman, B. W., and Post, J. E. (1996). Beyond the social contract: An analysis of the executive view at twenty-five larger companies. En D. T. Hall (Ed.), The career is dead - long live the career (pp. 46-71). San Francisco: Jossey-Bass.

Arthur, M. B., and Rousseau, D. M. (1996). The boundaryless career: A new employment principle for a new organizational era. New York: Oxford University Press.

Becker, G. S. (1964). Human Capital. New York: University of Chicago Press.

Brkich, M., Jeffs, D., and Carless, S. A. (2002). A Global SelfReport Measure of Person-Job Fit. European Journal of Psychological Assessment, 18, 43-51.

Brown, P., Hesketh, A., and Williams, S. (2003). Employability in a knowledge-driven economy. Journal of Education and Work, 16, 107-126.

Capelli, P. (1995). Rethinking employment. British Journal of Industrial Relations, 33, 563-602.

Cohen, J., Cohen, P., West, S., and Aiken, L. (2003). Applied multiple regression/correlation analysis for the behavioral sciences (3ra Ed). Hillsdale, NJ: Lawrence Erlbaum Associates.

Erdogan, B., and Bauer, T. N. (2005). Enhancing career benefits of employee proactive personality: the role of fit with jobs and organizations. Personnel Psychology, 58, 859-891.

Frese, M., and Fay, D. (2001). Personal initiative: An active performance concept for work in the 21 st century. In B. M. Staw and R. I. Sutton (Eds.), Research in Organizational Behavior (pp. 133-187). Greenwich, CT: JAI Press.

Frese, M., Kring, W., Soose, A., and Zempel, J. (1996). Personal initiative at work: Differences between East and West Germany. Academy of Management Journal, 39, 37-63.

Frese, M., Fay, D., Hilbuerger, T., Leng, L., and Tag, A. (1997). The concept of personal initiative: Operationalization, reliability and validity in two German samples. Journal of Occupational and Organizational Psychology, 70, 139-161.

Forrier, A., and Sels, L. (2003). The concept employability: a complex mosaic. International Journal of Human Resources Development and Management, 3, 102 - 124.

Fugate, M., Kinicki, A., and Ashforth, E. (2004). Employability: A psycho-social construct, its dimensions, and applications. Journal of Vocational Behavior, 65, 14 - 38.

García-Montalvo, J., Peiró, J. M., and Soro Bonmatí, A. (2003). Capital Humano. Observatorio de la Inserción Laboral de los Jóvenes: 1996-2002. Valencia: Bancaja-Ivie.

Gazier, B. (1998). Employability: definitions and trends. In B. Gazier (Ed.), Employability: Concepts and Policies (pp. 37-71). Berlin: European Employment Observatory. 
Gracia, F. J., Martínez-Tur, V., and Peiró, J. M. (2001). Tendencias y controversias en el futuro de la gestión y el desarrollo de los recursos humanos. In E. Agulló and Ovejero (Eds.), Trabajo, Individuo y Sociedad: Perspectivas psicosociológicas sobre el futuro del trabajo. Madrid: Pirámide.

Guest, D., and Conway, N. (2002). Communicating the psychological contract: An employer perspective. Human Resource Management Journal, 12, 22-38.

Herriot, P., and Pemberton, C. (1995). New Deals: The Revolution in Managerial Careers. Chichester, Sussex: John Wiley.

Herriot, P., and Pemberton, C. (1997). Facilitating New Deals. Human Resources Management Journal, 7, 45-56.

Hillage, J., and Pollard, E. (1998). Employability: developing a framework for policy analysis. London: DfEE.

Kochan, T. A. (1998). Back to Basics: Creating the Analytical Foundation for the Next Industrial Relations System. Paper presented in IRRA 50th Anniversary Meeting, January 3-5. Chicago, USA.

Kristof, A. L., Zimmerman, R. D., and Johnson, E. C. (2005). Consequences of Individuals' Fit at Work: A Meta-Analysis of Person-Job, Person-Organization, Person-Group, and PersonSupervisor Fit. Personnel Psychology, 58, 281-342.

McArdle, S., Waters, L., Briscoe, J. P., and Hall, D. T. (2007). Employability during unemployment: Adaptability, career identity and human and social capital. Journal of vocational behavior, 71, 247-264.

McQuaid, R.W., and Lindsay, C. (2005). The Concept of Employability. Urban Studies, 42, 197-219.

Nunnaly, J. C., and Berstein, I. H. (1994). Psychometric Theory (3ra ed.). New York: McGraw Hill.

Peiró, J. M., García-Montalvo, J., and Gracia, F. (2002). How do young people cope with job flexibility? Demographic and psychological antecedents of the resistance to accept a job with non-preferred flexibility features. Applied Psychology: AnInternational Review-Psychologie Appliquee-Revue Internationale, 51, 43-66.
Pinazo, D., Peiró, J. M., Carrero, V., and Rosel, J. (1999). Influencia del comportamiento proactivo de carrera en el cambio del desfit positivo de expectativas. Revista de Psicología Social Aplicada, 9, 73 - 94.

Ripoll, P., Rodríguez, I., Hontangas, P., Peiró, J. M., and Prieto, F. (1994). "Perspectivas de empleo". In F. Prieto et al. (Dirs.), Los jóvenes ante el ambiente laboral y las estrategias de adaptación (pp. 81-87). Valencia: Nau Llibres.

Rothwell, A., and Arnold J. (2007). Self-perceived employability: development and validation of a scale. Personnel Review, 36, 23-41.

Rousseau, D. M. (2001). The Idiosyncratic Deal: Flexibility versus Fairness? Organizational Dynamics, 29, 260-273.

Rousseau, D.M. (2005). I-deals: Idiosyncratic deals employees bargain for themselves. New York: M.E. Sharpe.

Rousseau, D., Ho, V., and Greenberg, J. (2006). I-deals: Idiosyncratic terms in employment relationships. The Academy of Management Review, 31, 977- 994.

Sullivan, S. E. (1999). The Changing Nature of Careers: A review and Research Agenda. Journal of Management, 25, 457484.

Stumpf, S. A., Colarelli, S., and Hartman, K. (1983). Development of the Career Exploration Survey (CES). Journal of Vocational Behavior, 22, 191-226.

Tsui, A. S., Pearce, J. L., Porter, L. W., and Tripoli, A. M. (1997). Alternative Approaches to the employee-organization relationship: Does investment in employees pay off? Academy of Management Journal, 40, 1089-1121.

Vila, L. E. (2000). The non-monetary benefits of education. European Journal of Education, 35, 21-32.

Vila, L. E. (2005). The Outcomes of Investment in Education and People's Well-being. European Journal of Education, 40, 3-11.

Received January 8, 2008 Revision received July 4, 2008 Accepted September 22, 2008 